\title{
CUSTOMER SATISFACTION LEVEL TOWARDS CREDIT CARD
}

\author{
Vuong Duc Hoang Quan \\ Ho Chi Minh City Institute for development studies
}

(Received: 20/05/2014; Revised: 20/06/2014; Accepted: 28/7/2014)

\begin{abstract}
The use of credit card plays a very important role in online purchasing and contributes significantly to the economy of one nation. Due to the under-developed infrastructure and purchasing habit, credit card transaction still takes a very small proportion and promises a very large space to develop. The purpose of this research is to measure customer satisfaction towards the credit cards they are using. Applying the Five Broad Dimensions theory, the research forms a survey that fits into the Five Broad Dimensions. There are two main analyses completed in the research including descriptive and correlation. The descriptive analysis is conducted to point out some specific areas in which banks or card providers need to pay more attention. The correlation analysis is to find out how strong the relationship between each independent variable and the dependent variable. Finally, the conclusion and recommendation will summarize the key findings of the research and give suggestions to the card issuers.
\end{abstract}

Keywords: satisfaction, satisfaction level, customer service, banking service.

\section{Introduction}

Only started in 1996 , the payment card market in general and the credit card market in particular, have been developing positively. Still, in compare to more developed card markets such as EU and US, the credit card market in Vietnam is just at the beginning stage.

According The State Bank of Vietnam, the cardholder ratio is very low: only about 2.43 million credit cards (Vietnamnews, 2014) in 88.8 million people. In big residence areas, in 109 people only 1 uses credit card. Also, according to Vietnam Bank Card Association, there are totally about 66.2 million payment cards in 2010, including both ATM and debit cards. However, in reality a high number of ATM and debit cards have never been activated and most of debit card transactions are performed at ATM rather than at merchants.

Obviously, the proportion of credit card to the whole payment card is quite low; one of the reasons is possibly the issuing fee. Nonetheless, once being persuaded to pay fees willingly, credit cardholder makes payment more often than debit cardholder does.

However, The State Bank of Vietnam also showed that the credit card market is growing fast as the last year number of credit cards issued increased $22 \%$ over 2012 (Vietnamnews, 2014). A big potential market is right here and banks are becoming much more competitive in the payment card market. At the end of 2013, there are 52 banks are offering credit cards.

With the card payment value currently only takes $3.5 \%$ of the whole payment system (The State Bank of Vietnam, 2013), the potential is serious and a lot can be done to turn it into regular paying habit. Increasing customer satisfaction is the very first factor that counts. Once customers are completely satisfied with their purchase payment, they will tend to use credit cards more due to its convenience and credit limit. As a result, banks will earn more profit through card fees, 
transaction fees and interest on the credit that customers use. The convenience of credit card will play an important role to improve purchasing and contribute to the economy of Vietnam.

\section{Liturature review}

\section{importance \\ 2.1. Customer satisfaction and its}

According to Coldwell (2001), a customer who is fully satisfied may help a firm to generate 2.6 times as much revenue as the one who is somehow satisfied. Moreover, a completely dissatisfied customer may cause a 1.8 times decrease in revenue as compared to a completely satisfied customer. Zairi (2000) states that satisfied customers would recommend the services they use to the other 5 or 6 people and dissatisfied customers would tell the bad experience to 10 people. More seriously, not all customers give their complaints to service providers and in many cases, it is very hard for service providers to get opinions from their customers.

Moreover, customer loyalty will help business to gain much more profit as it costs much more to acquire new customers than to retain a loyal customers, in terms of marketing expense. Anton (1996) claims that improving customer loyalty will lead to the rise of existing-product sales, cross purchase, markup premium and the decline of operating cost. Furthermore, businesses may take advantage of word of mouth from loyal customers for their brand building. Levesque and McDougall (1996) pointed out that retail banks that are able to increase customer loyalty may reduce service cost, better understand customer needs, build up their knowledge about financial affairs and improve sales of both existing and new products.

\subsection{Drivers of customer satisfaction}

Service quality is defined as an international standard of evaluation for the overall quality of services (Parasuraman et al, 1990). Besides, service quality is defined as the difference between the expectations for the service encountered and the perceptions of the service received. According to the service quality theory (Oliver, 1980), customers perceive the quality of services low if the performance does not meet their expectations and high if performance exceeds their expectations. Therefore, it is crucial for service providers to grasp customer expectations.

Measuring service quality in banking industry is a difficult task due to the industry characteristics: intangibility, heterogeneity, inseparability and perish-ability (Parasuraman, et al, 1990). Because of these complexities, various measuring models have been developed to evaluate perceptions of service quality (Parasuraman et al, 1990; Stafford, 1996; Bahia and Nantel, 2000).

Parasuranman et al. (1985) proved that service quality have dimensions such as reliability, responsiveness, competence, access, courtesy, communication, credibility, security, understanding/ knowing the customer, and tangibility. In 1988, these ten dimensions were consolidated to only five: tangibility, reliability, responsiveness, assurance and empathy. These Five Broad Dimensions reflect both expectations and perceived performance.

Five Broad Dimension of Service Quality (Parasuraman et al, 1990)

Tangible: Appearance of physical facilities, equipment, personnel, and communication materials

Specific Illustrative Criteria

- Appearance of physical facilities

- Appearance of service personnel

- Appearance of tools or equipment used to provide service

Reliability: Ability to perform the promised service dependably and accurately

Specific Illustrative Criteria

- Accuracy of billing or record keeping

- Performing services when promised

- Dependable and accurate performance

Responsiveness: Willingness to help 
customers and provide prompt service

Specific Illustrative Criteria

- Providing prompt service

- Readiness to service

- Handling of urgent request

- Promptness and Helpfulness

Assurance: Knowledge and courtesy and ability to win trust and confidence of customer

\section{Specific Illustrative Criteria} security

- Competence, courtesy, creditability and

Empathy: Caring, easy access, good / communication, customer understanding and individualized attention given to customers

Specific Illustrative Criteria

- Listening to customer needs

- Caring about customers' need

- Providing personalized attention

- Easy Access

- Good communication with customer

- Understanding

\section{Methodology}

\subsection{Research Framework}

The research applied the Five Broad Dimensions of Service Quality mentioned in "Delivering Quality Service: balancing customer perceptions and expectations" (Parasuraman et al ,1990) as a framework to build up the survey used for quantitative research. Before conducting the survey, a qualitative research by interview is made to collect opinions of experts and experienced credit card holders. The main purpose is to form the best survey that points out the most important factors related to credit card users' satisfaction.

There are Five Broad Dimensions that later are served for five independent variables including Tangibility (x1), Reliability (x2), Responsiveness (x3), Assurance (x4) and
Empathy (x5). The dependent variable is the satisfaction level $(\mathrm{y})$ which credit card users rank for.

For Tangibility, the related issues brought into the research include the quality of credit card material, the comprehension of user guide, the quality of ATM machine and ATM booth and the appearance of customer service staff. The quality of credit card material determines the card durability and the design of the card would attract users and play a role of marketing tool for the card issuers. The user guide should be easy to understand and cover common issues customers may encounter. The ATM system and quality is important for customers who often need to withdraw cash. The two importance issues to consider are the convenience that is the number of ATMs and the ATM booths. Customer service staff who works at banks needs to provide adequate information and benefits of credit card to new customers.

For Reliability, there are two main issues which are phone answering staff's knowledge about credit card and the online banking system that assists card users. Staff needs to be trained adequately so they may quickly locate problems and figure out the solutions for customers. The online banking system must support customers, especially for the purposes such as reviewing billing statements, transferring money or making payments.

For Responsiveness, the research takes into consideration 3 issues including staff's willingness to assist customers, staff's problem solving skills and their ability to perform professional services. Phone answering staff may face a wide range of situations of which they may have to solve problems hardly encountered before. Therefore, they have to show willingness to listen customers and patient enough to walk them through the difficulties. The problem solving skills must be good so that problems are not just solved quickly, adequately but customers also feel satisfied with the solutions given by the staff. Moreover, as banking industry requires a very high level of professional in order to gain trust from customers, staff needs to show their 
professional at a very high level to customers.

For Empathy, there are two important issues including upgrade program and reward program. Customers who used card for a certain period often want to upgrade their cards for more benefits; therefore, banks need to provide them reasonable upgrade program to encourage customers. The reward programs that linked with the merchants are also very important to attract customers. Banks with more rewards programs may meet demand of a higher number of customers thus have a better chance to expand its market.

Table 1. Independent and Dependent variables in the research

\begin{tabular}{|c|c|c|}
\hline No. & Code & Item \\
\hline \multicolumn{3}{|c|}{$\begin{array}{l}\text { Tangibility (x1) - Appearance of physical facilities, equipment, personnel, and communication } \\
\text { materials }\end{array}$} \\
\hline 1 & Tan1 & - Quality of the credit card \\
\hline 2 & Tan2 & - Comprehension of user guide \\
\hline 3 & Tan3 & - ATM quality \\
\hline 4 & Tan4 & - Appearance of customer service staff \\
\hline \multicolumn{3}{|c|}{ Reliability (x2) - Ability to perform the promised service dependably and accurately } \\
\hline 5 & Rel1 & - Staff knowledge \\
\hline 6 & Rel2 & - Online banking system to review billing statements \\
\hline \multicolumn{3}{|c|}{ Responsiveness (x3) - Willingness to help customers and provide prompt service } \\
\hline 7 & Res1 & - Staff willingness to assist customers \\
\hline 8 & Res2 & - Staff's problem solving skills \\
\hline 9 & Res3 & - Staff's ability to perform professional service \\
\hline \multicolumn{3}{|c|}{ Assurance (x4)- Knowledge and courtesy and ability to win trust and confidence of customer } \\
\hline 10 & Ase1 & - Offline transaction security \\
\hline 11 & Ase2 & - Online transaction security \\
\hline \multicolumn{3}{|c|}{$\begin{array}{l}\text { Empathy (x5) - Caring, easy access, good /communication, customer understanding and } \\
\text { individualized attention given to customers }\end{array}$} \\
\hline 12 & Emp1 & - Upgrade program \\
\hline 13 & Emp2 & - Reward program \\
\hline \multicolumn{3}{|c|}{ Satisfaction level (y) - the satisfaction level credit card users give for their use of the cards. } \\
\hline 14 & Sat1 & - Satisfaction in general \\
\hline
\end{tabular}




\subsection{Data Collection and Data Analysis}

In common practice, $\alpha$ is often set at 0.05 when power is 0.80 to have a confident result of statistic. Green (1991) has summarized study of Cohen (1988) about effect sample size in the Table 2 below:

Table 2. Effect on sample size (Green, 1991)

\begin{tabular}{|c|c|c|c|c|c|c|}
\hline \multirow{2}{*}{$\begin{array}{c}\text { Number of } \\
\text { predictors }\end{array}$} & \multicolumn{3}{|c|}{ Sample sizes based on power analysis } & \multicolumn{3}{c|}{ Sample sizes based on new rule of thumb } \\
\cline { 2 - 7 } & Large & Medium & Small & Large & Medium & Small \\
\hline 1 & 390 & 53 & 24 & 400 & 53 & 23 \\
\hline 2 & 481 & 66 & 30 & 475 & 63 & 27 \\
\hline 3 & 547 & 76 & 35 & 545 & 73 & 31 \\
\hline 4 & 599 & 84 & 39 & 610 & 81 & 35 \\
\hline 5 & 645 & 91 & 42 & 670 & 89 & 38 \\
\hline 6 & 686 & 97 & 46 & 725 & 97 & 41 \\
\hline 7 & 726 & 102 & 48 & 775 & 103 & 44 \\
\hline 8 & 757 & 108 & 51 & 820 & 109 & 47 \\
\hline 9 & 788 & 113 & 54 & 860 & 115 & 49 \\
\hline 10 & 844 & 117 & 56 & 895 & 119 & 51 \\
\hline 15 & 952 & 138 & 67 & 1045 & 139 & 60 \\
\hline 20 & 1066 & 156 & 77 & 1195 & 159 & 68 \\
\hline 30 & 1247 & 187 & 94 & 1495 & 199 & 85 \\
\hline 40 & 1407 & 213 & 110 & 1795 & 239 & 103 \\
\hline
\end{tabular}

Sample size required to test the hypothesis that the population multiple correlation equals Zero with a Power of $0.80($ Alpha $=0.05)$

According to Green (1991), a study in behavior statistic should have medium effect size and the minimum number of subjects required for study with this effect size according to the table above. This thesis studies 14 indicators including Satisfaction Level which is between range of 10-15. Therefore, a sample size of 117 to 138 objects is sufficient to create a effective study.

The research used Rating Scale survey in which there are 5 levels of satisfaction, 1 is lowest and 5 is highest. The first part of the research is to ask for respondents' biography, including age range, gender, income range, and education. The survey is distributed via email to
550 people working at Ho Chi Minh City and there are 200 respondents who completed the whole survey. The respondents age ranges from 25 to 45 and $46.5 \%$ of them are male. Their income range is from $\$ 1,000$ to $\$ 3,000$. Ninety two percent of them have Bachelor degree and the rest earns Master degree.

Among the Five Broad Dimensions, Assurance is considered the most important factor that drive customer Satisfaction Level. As credit card use in Vietnam is still in developed process and cash still plays the most important role in payment, customers have a real concern about security, especially when credit card fraud becomes much more popular. 
Besides, Tangibility, though appears as one of the Five Broad Dimensions for customer satisfaction, seems to have a smaller impact on credit card users. As a result, the research has the two following hypotheses:

Hypothesis 1: Assurance has the strongest correlation with customer satisfaction

Hypothesis 2: Tangibility has the weakest correlation with customer satisfaction

One of the previous related research to this subject is "Factors Affecting to Card Payment's Choice: An empirical study of HCM city, Vietnam", also written by. Vuong Duc Hoang Quan and his partner- Nguyen Dong Phuong (2013). The research points out why cash transactions still remain very popular and take much larger proportion in the total payment value in Vietnam. Several factors such as Ease of Use, Security, Ability to control expense, Cost of using cards and Rewards are taken into consideration to find out how they affect customers' decisions to use card at POS other than cash. The result finding of the previous research is considered as reference for this research to bring up more important issues for further studies.

\section{Findings}

\subsection{Descriptive analysis}

From the survey result, mean of satisfaction level of each item and weighted mean of each dimension were calculated. Table 3 shows the average of satisfaction level of each item and Table 5 shows the weighted average of items in each Dimension. The result clearly demonstrates areas that banks may have to pay more attention.

Table 3. Average points of each item calculated from the survey result

\begin{tabular}{llr}
\hline Code & Item & Mean \\
\hline Tan1 & - Quality of the credit card & 2.89 \\
Tan2 & - Comprehension of user guide & 2.58 \\
Tan3 & - ATM quality & 3.55 \\
Tan4 & - Appearance of customer service staff & 3.33 \\
Rel1 & - Staff knowledge & 2.88 \\
Rel2 & - Online banking system to review billing statements & 3.55 \\
Res1 & - Staff willingness to assist customers & 2.79 \\
Res2 & - Staff's problem solving skills & 2.49 \\
Res3 & - Staff's ability to perform professional service & 2.66 \\
Ase1 & - Offline transaction security & 2.99 \\
Ase2 & - Online transaction security & 3.64 \\
Emp1 & - Upgrade program & 3.18 \\
Emp2 & - Reward program & 3.22 \\
Sat1 & - Satisfaction in general & 3.15 \\
\hline
\end{tabular}


Table 4. Mean ranking of independent variables

\begin{tabular}{llr}
\hline Code & Item & Mean \\
\hline Res2 & - Staff's problem solving skills & 2.49 \\
Tan2 & - Comprehension of user guide & 2.58 \\
Res3 & - Staff's ability to perform professional service & 2.66 \\
Res1 & - Staff willingness to assist customers & 2.79 \\
Rel1 & - Staff knowledge & 2.88 \\
Tan1 & - Quality of the credit card & 2.89 \\
Ase1 & - Offline transaction security & 2.99 \\
Emp1 & - Upgrade program & 3.18 \\
Emp2 & - Reward program & 3.22 \\
Tan4 & - Appearance of customer service staff & 3.33 \\
Rel2 & - Online banking system to review billing statements & 3.55 \\
Tan3 & - ATM quality & 3.55 \\
Ase2 & - Online transaction security & 3.64 \\
\hline
\end{tabular}

Table 5. Weighted average of each Dimension

\begin{tabular}{llr}
\hline Code & Item & Mean \\
\hline Tan & Tangibility & 3.08 \\
Rel & Reliability & 3.19 \\
Res & Responsiveness & 2.65 \\
Ase & Assurance & 3.14 \\
Emp & Empathy & 3.20 \\
\hline
\end{tabular}

Then the correlation analysis will be executed to determine how strong the relationship between dependent and independent variables. The Pearson correlation varies from +1 in the case of a perfect positive correlation to -1 in the case of a perfect negative correlation. If the two variables have no relationship, Pearson's correlation is equal to 0 .

\subsection{Reliability analysis}

To examine the reliability of the survey results, the research applied Cronbach's Alpha test. Table 6 extracted from the test shows that the Cronbach's alpha is 0.953 which means that the internal consistency is very high. Among the variables, only Tan 1 and Tan3 cause the increase of Cronbach's Alpha if being deleted. However, the difference is minimal thus these two variables are still usable. 
Table 6. Cronbach's alpha on independent variables

\begin{tabular}{|l|l|l|}
\hline $\begin{array}{c}\text { Cronbach's } \\
\text { Alpha }\end{array}$ & $\begin{array}{c}\text { Cronbach's Alpha Based } \\
\text { on Standardized Items }\end{array}$ & N of Items \\
\hline .953 & .954 & 13 \\
\hline
\end{tabular}

Item-Total Statistics

\begin{tabular}{|l|r|r|r|r|r|}
\hline & $\begin{array}{c}\text { Scale Mean if } \\
\text { Item Deleted }\end{array}$ & $\begin{array}{c}\text { Scale Variance } \\
\text { if Item Deleted }\end{array}$ & $\begin{array}{c}\text { Corrected } \\
\text { Item-Total } \\
\text { Correlation }\end{array}$ & $\begin{array}{c}\text { Squared } \\
\text { Multiple } \\
\text { Correlation }\end{array}$ & $\begin{array}{c}\text { Cronbach's } \\
\text { Alpha if Item } \\
\text { Deleted }\end{array}$ \\
\hline Tan1 & 36.4500 & 102.761 & .297 & .180 & .963 \\
Tan2 & 36.7350 & 96.769 & .869 & .841 & .947 \\
Tan3 & 35.7700 & 106.037 & .251 & .103 & .961 \\
Tan4 & 36.0100 & 93.779 & .777 & .658 & .949 \\
Rel1 & 36.4300 & 93.844 & .818 & .741 & .948 \\
Re12 & 35.8250 & 94.286 & .839 & .759 & .947 \\
Res1 & 36.5300 & 92.522 & .868 & .776 & .946 \\
Res2 & 36.8300 & 93.257 & .898 & .859 & .946 \\
Res3 & 36.6550 & 88.599 & .950 & .929 & .943 \\
Ase1 & 36.3350 & 92.817 & .857 & .768 & .946 \\
Ase2 & 36.0200 & 94.784 & .846 & .750 & .947 \\
Emp1 & 36.1400 & 94.915 & .824 & .845 & .948 \\
Emp2 & 36.1100 & 91.696 & .895 & .945 \\
\hline
\end{tabular}

After checking the reliability of each independent variable, the research examined the reliability of each dimension. The result in Table 7 demonstrates that a very high internal consistency as Cronbach's alpha is 0.959 . Among the dimensions, only Tangibility (Tan) if being deleted makes Cronbach's Alpha slightly increases.

Table 7. Cronbach's alpha on each dimension

Reliability Statistics

\begin{tabular}{|r|r|r|}
\hline Cronbach's Alpha & $\begin{array}{c}\text { Cronbach's Alpha Based on } \\
\text { Standardized Items }\end{array}$ & N of Items \\
\hline .959 & .962 & 5 \\
\hline
\end{tabular}

\begin{tabular}{|l|r|r|r|r|r|}
\hline & $\begin{array}{c}\text { Item-Total Statistics } \\
\text { Item Deleted }\end{array}$ & $\begin{array}{c}\text { Scale Variance } \\
\text { if Item Deleted }\end{array}$ & $\begin{array}{c}\text { Corrected } \\
\text { Item-Total } \\
\text { Correlation }\end{array}$ & $\begin{array}{c}\text { Squared } \\
\text { Multiple } \\
\text { Correlation }\end{array}$ & $\begin{array}{c}\text { Cronbach's } \\
\text { Alpha if Item } \\
\text { Deleted }\end{array}$ \\
\hline Tan & 12.1780 & 13.359 & .805 & .660 & .966 \\
Rel & 12.0643 & 11.238 & .897 & .832 & .948 \\
Res & 12.6088 & 10.389 & .951 & .909 & .939 \\
Ase & 12.1143 & 11.159 & .910 & .847 & .945 \\
Emp & 12.0618 & 10.963 & .911 & .840 & .945 \\
\hline
\end{tabular}




\section{Correlation analysis}

In the bivariate correlation report shown in the below Table 8, all Pearson correlation indicators are above 0 that means that all independent variables have strong influence towards the dependent variable. In term of customer satisfaction, Tangibility and Empathy have the lowest correlation at 0.842 and 0.864 respectively while Assurance has highest correlation at 0.920 . The positive values of Pearson correlation indicate that customer satisfaction at any Dimension contributes to the general customer satisfaction toward credit card.

Besides, p-value of all correlation coefficients are 0.000 that means that the Five Broad Dimensions have linear relationship with the Satisfaction Level of credit card users. One interesting finding of the research is the strong correlation among the Five Broad
Dimensions. This could be explained that credit card users who have high requirements for customer service tend to rate lower than those who have lower requirements for any item they are questioned. Another possible explanation is that some card providers (commercial banks) have much lower customer service quality overall; therefore, the rating for each dimension and the general satisfaction are low.

Based on the correlation analysis result, the research accepts the two hypotheses that (1) Assurance has the strongest correlation with customer satisfaction and (2) Tangibility has the weakest correlation with customer satisfaction. One important point is that independent variables have strong correlation to each other thus make regression analysis unusable.

Table 8. Pearson Correlation among Five Broad Dimensions

\begin{tabular}{|c|c|c|c|c|c|c|c|}
\hline & & Sat1 & Tangibility & Reliability & Responsiveness & Assurance & Empathy \\
\hline \multirow[t]{3}{*}{ Sat1 } & $\begin{array}{l}\text { Pearson } \\
\text { Correlation }\end{array}$ & 1 & $.842^{* *}$ & $.901^{* *}$ & $.899^{* *}$ & $.920^{* *}$ & $.864^{* *}$ \\
\hline & Sig. (2-tailed) & & .000 & .000 & .000 & .000 & .000 \\
\hline & $\mathrm{N}$ & 200 & 200 & 200 & 200 & 200 & 200 \\
\hline \multirow[t]{3}{*}{ Tangibility } & $\begin{array}{l}\text { Pearson } \\
\text { Correlation }\end{array}$ & $.842^{* *}$ & 1 & $.858^{* *}$ & $.901^{* *}$ & $.864^{* *}$ & $.847^{* *}$ \\
\hline & Sig. (2-tailed) & .000 & & .000 & .000 & .000 & .000 \\
\hline & $\mathrm{N}$ & 200 & 200 & 200 & 200 & 200 & 200 \\
\hline \multirow[t]{3}{*}{ Reliability } & $\begin{array}{l}\text { Pearson } \\
\text { Correlation }\end{array}$ & $.901^{* *}$ & $.858^{* *}$ & 1 & $.925^{* *}$ & $.901^{* * *}$ & $.913^{* *}$ \\
\hline & Sig. (2-tailed) & .000 & .000 & & .000 & .000 & .000 \\
\hline & $\mathrm{N}$ & 200 & 200 & 200 & 200 & 200 & 200 \\
\hline \multirow{3}{*}{ Responsiveness } & $\begin{array}{l}\text { Pearson } \\
\text { Correlation }\end{array}$ & $.899^{* *}$ & $.901^{* *}$ & $.925^{* *}$ & 1 & $.906^{* *}$ & $.903^{* *}$ \\
\hline & Sig. (2-tailed) & .000 & .000 & .000 & & .000 & .000 \\
\hline & $\mathrm{N}$ & 200 & 200 & 200 & 200 & 200 & 200 \\
\hline \multirow[t]{3}{*}{ Assurance } & $\begin{array}{l}\text { Pearson } \\
\text { Correlation }\end{array}$ & $.920^{* *}$ & $.864^{* *}$ & $.901^{* *}$ & $.906^{* *}$ & 1 & $.873^{* *}$ \\
\hline & Sig. (2-tailed) & .000 & .000 & .000 & .000 & & .000 \\
\hline & $\mathrm{N}$ & 200 & 200 & 200 & 200 & 200 & 200 \\
\hline \multirow[t]{3}{*}{ Empathy } & $\begin{array}{l}\text { Pearson } \\
\text { Correlation }\end{array}$ & $.864^{* *}$ & $.847^{* *}$ & $.913^{* *}$ & $.903^{* *}$ & $.873^{* *}$ & \\
\hline & Sig. (2-tailed) & .000 & .000 & .000 & .000 & .000 & \\
\hline & $\mathrm{N}$ & 200 & 200 & 200 & 200 & 200 & 200 \\
\hline
\end{tabular}




\section{Discussion}

From the descriptive analysis, the research points out specific areas that credit card holders need to improve in order to achieve higher satisfaction from customers. First, most of credit card users are not satisfied with the quality of credit card (Mean $=2.89)$ and details of user guide provided (Mean = 2.58). As credit card is still new in Vietnam, commercial banks should offer better brochure and guidance materials to help customers, especially who are not familiar with online payment and credit card use. Second, every time when customers have problems with their cards, whether they are lost or stolen, customers didn't receive necessary and adequate supports from the phone answering staff, this is clearly proved with the weighted average Responsiveness of only 2.65 . In general, their problem solving skills needs are quite poor as problems are not located quickly and solutions did not satisfy customers (Mean $=2.49$, lowest in the survey result). Moreover, banks should recheck their automatic phone answering system to ensure that it guides customers reasonably when they call banking core center for help.

On the other side, customers feel very good at three areas such as quality of ATM machine booth (Mean $=3.55)$, the presentation of the billing statements (Mean = 3.55) and especially their confidence when shopping online (Mean $=3.64$, highest in the test). Since online shopping will become more important in Vietnam market in upcoming years, the confidence of customers to make payments with their cards is very important, not just important for the bank who will generate much more profit but also for merchants who offer online shopping to consumers. As the number of online purchasing transactions in Vietnam is still very small compared with developed countries, banks still face less pressure to improve its security system. However, since the use of credit cards would be increased significantly, banks must develop more secured system for credit card users.

From the correlation analysis, the research shows the relationship between independent and dependent variables. The Five Broad Dimensions have strong relationship with the Satisfaction Level of credit card users. This means that banks need to pay more attention of requirements credit card users:

Tangibility - the quality of credit card material need to be good and durable. The design, if possible, should be attractive or customizable. User guidance should be clear, simple and updated.

Reliability - the phone answering staff should be available to support customers, especially in case they have serious problems such as credit card fraud. Banks should improve the phone answering system to reduce the waiting time and add more answering staff if necessary.

Responsiveness - not just be available, customer service staff needs to give customers useful supports. They should quickly locate the problems and solve or transfer them to those who own responsibility to solve those problems

Assurance - this is the most important issue banks have to pay attention in order to improve customer satisfaction. Customers should feel safe and confident to use their cards. The sums system some banks are currently using have proved its ability to keep customers updated and feel safe. Text message is sent every time any purchase is made thus allow customers to report fraudulent immediately.

Sympathy - customers feel satisfied with the benefits banks offer together with the credit cards. The discount and reward programs do not only make customers feel being appreciated but also create purchasing habits at merchants which are linked with banks.

Compared with the research "Factors Affecting to Card Payment's Choice: An empirical study of HCM city, Vietnam" of Vuong Duc Hoang Quan and Nguyen Dong Phuong (2013) this research points out the instruments that affect Satisfaction Level of credit card users. While the previous research 
focuses on the factors that drive people to use cards other than cash when making payments, this research approaches the evaluation of customer satisfaction with all related services they received. A couple of common issues the two researches encounter includes security of credit card payments, the reward programs related to the use of card and how easy and comfortable the card users feel when making payments via their cards. Overall, security issue still plays the most important role driving credit card users' behaviors, whether they choose to use cards to make payments or they feel happy with the use of cards. The reward programs encourage customers to use their cards for additional benefits in addition to the convenience and credit borrowing.

\section{Conclusion and suggestion for further research}

In summary, the research points out that all of the Five Broad Dimensions have influence on the Satisfaction Level of credit card users. Of which, the research accepts two hypotheses that the Assurance take the most important place while Tangibility has minimal impact on customers. Responsiveness is an area where customers show the lowest satisfaction and Assurance earns the highest concern from customers in terms of credit card usage. From the research, a suitable model is built to evaluate the Satisfaction Level based on the three most important Dimensions including Assurance, Reliability and Responsiveness. To encourage customers to change their habits in making payment from using cash to using credit cards, commercial banks must pay attention on many issues related to different stages that credit card users involved with, from the opening the cards, using and getting familiar with credit card to solving problems occurred with card usage.
One of the most important tasks for the banks is to improve the credit card security and protection. As the total payment value via credit card grows quickly, credit card fraud rises significantly. Therefore, banks have to consider two things: (1) improve the security system to limit the fraud such as creating different layers of protection and confirmation before transactions executed (2) improve the ability to solve problems related to credit card fraud such as collecting the money involved with fraudulent and limit the loss occurred.

Second, since the profit generated by credit card use is enormous, the competition among commercial banks to grab market share is rising quickly. As a result, banks have to consider the two important issues that are the Reliability and Responsiveness. The staff or credit card advisors at banks must give customers adequate information and guidance from how to use the card properly and securely to how to get more benefits with the cards they acquire. If customers are encouraged by the additional benefits related to the use of credit cards, they may feel more willing to make payments with the cards. Furthermore, the phone answering staff needs to be trained to perform professional support to customers. As communication via phone is much more complex than face to face, staff must be prepared well about problem and situation solving skills to achieve the highest satisfaction from customers.

The research has two main limitations. First, it is conducted only in Ho Chi Minh City. Second, the survey is distributed to office staff of big corporations. As a result, further studies that cover other regions of Vietnam and expand to more types of subjects may bring up a broader view to the topic of concern.

\section{REFERENCES}

Anton, J. (1996). "Customer Relationship Management: Making Hard Decisions with Soft Numbers". Upper Saddle River, Prentice-Hall, New Jersey, US.

Bahia, K and Nantel, J. (2000). "A reliable and valid measurement scale for the perceived service quality of banks". International Journal of Bank Marketing. Vol 18 No.2, pp. 84. 
Coldwell, J. (2001). "Characteristics of a Good Customer Satisfaction Survey”. Tata McGrawHill, India.

Levesque, T and McDougall, G. (1996). "Determinants of customer satisfaction in retail banking". International Journal of Bank Marketing, Vol. 14 No. 7, pp. 12-20.

Oliver, R. (1980). "A cognitive model of the antecedents and consequences of satisfaction decisions". Journal of Marketing Research, Vol 17, pp. 460-469.

Parasuraman et al. (1990). Delivering Quality Service. The Free Press, New York, US

Green, S. (1991). "Multivariate behavior research". Taylor and Francis Online, Vol. 26 No 3, pp. $499-510$.

Stafford, M. (1996). "Demographic discriminators of service quality in the banking industry". The Journal of Services Marketing, Vol. 10 No.4, pp. 6.

Vietnamnews (2014). "Credit payments edge up in cash-only society”. Viet Nam News. $8^{\text {th }}$ Jul. 2014

[https:/www.google.com.vn/url?sa=t\&rct=j\&q=\&esrc=s\&source=web\&cd=1\&cad=rja $\& u$ act $=8 \&$ ved $=0 \mathrm{CBsQFjAA} \& u r l=\mathrm{http} \% 3 \mathrm{~A} \% 2 \mathrm{~F} \% 2 \mathrm{Fvietnamnews.vn} \% 2 \mathrm{Feconomy} \% 2 \mathrm{~F} 25214$ $1 \% 2$ Fcredit-payments-edge-up-in-cash-onlysociety.html\&ei=EQL0U7KZPMznsASP9YDICQ\&usg=AFQjCNFT1im8UIJCvJNai7xbtj EWqGG6fA\&sig2=ceNglvb0zU4sJh0rEygjTg\&bvm=bv.73231344,d.cWc $\}$

Vuong Duc Hoang Quan, and Nguyen Dong Phuong (2013). "Factors Affecting to Card Payment's Choice: An empirical study of HCM city, Vietnam”. Social Science Research Network, Nov. $7^{\text {th }} 2013$.

Zairi, M. (2000). "Managing Customer Dissatisfaction Through Effective Complaint Management Systems". The TQM Magazine, Vol. 12 No. 5, pp. 331-335. 